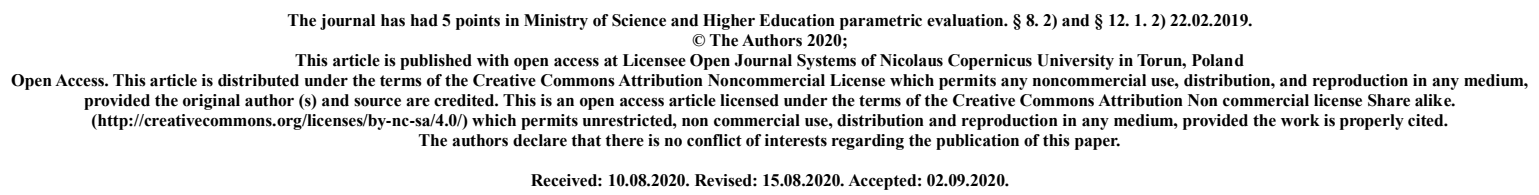

\title{
Hepatitis associated with parvovirus B19 infection in a 12-year-old-boy. Case report
}

\author{
Aleksandra Kowalik, Natalia Panasiuk, Elżbieta Pac-Kożuchowska
}

Lek. Aleksandra Kowalik

ORCID: 0000-0002-7083-5332

Department of Paediatrics and Gastroenterology, Medical University of Lublin, Al.

Racławickie 1, 20-059 Lublin, Tel. 817185 420, fax 7431353

e-mail: aleksandraguz@wp.eu

Lek. Natalia Panasiuk

ORCID: 0000-0002-6931-0619

Department of Paediatrics and Gastroenterology, University Children's Hospital, ul. prof. A. Gębali 6, 20-093 Lublin, Tel. 817185 420, fax 7431353

e-mail: npanasiuk1990@gmail.com

Prof. dr hab. n. med. Elżbieta Pac-Kożuchowska

ORCID: 0000-0002-3204-2235

Department of Paediatrics and Gastroenterology, Medical University of Lublin, Al.

Racławickie 1, 20-059 Lublin, Tel. 817185 420, fax 7431353

e-mail: elzbietapackozuchowska@umlub.pl 


\begin{abstract}
Parvovirus B19 infection is one of the most common viral diseases manifested with a rash in school children. The vast majority of rare clinical forms of parvovirus B19 infection are associated with hepatitis. We present the case of a 12-year-old boy with parvovirus B19associated hepatitis.
\end{abstract}

Key words: Parvovirus; Infections; Hepatitis; Child

\title{
Introduction
}

Parvovirus B19 was discovered accidentally in 1974 (during tests for surface antigen of hepatitis B virus in blood donors) and is the only member of the Parvoviridae family known to be pathogenic for humans $(1,2)$.

Parvovirus B19 is a small DNA-containing single-strandedvirus (only 18-26 nm): thus, it is 10 times smaller than the biggest viruses pathogenic for humans, i.e. poxviruses. The capsid of these viruses is anicosahedron composed of 12 pentametric capsomeres- in total, 60 subunits consisting of various proteins(VP1-VP6) andis sheath-free. Therefore, parvovirus B19 is extremely resistant to physical inactivation. It stays stable at $56^{\circ} \mathrm{C}$ for 60 minutes andlipid solvents do not affect it $(2,3,4)$.

The virus is widespread, and the symptoms of infection vary depending on the immune and haematologic status of the host. Parvovirus B19 infections affect all age groups. The serological indices of the infection are found in $2-10 \%$ of children below the age of 5 years and in about $50 \%$ of adolescents; at the age of 70 this percentage increases to $90-100 \%$ $(1,4,5)$.

In healthy children, parvovirus B19 infection manifests as erythema infectiosus (fifth disease). The disease presents as a lace-like rash (butterfly or slapped cheek)initially located on the face and then on the extremities; in most cases, the rash does not affect the trunk, hands, feet, and mucous membranes. In some cases, particularly in adults, the disease is associated with acute symmetric polyarthropathy, which may mimic rheumatoid arthritis. Due to the tropism ofB19 to erythroid progenitor cells, the infection causes transient aplastic crisis in individuals with haemolytic disorders. In immunocompromised individuals the persistent B19 infection often manifests as pure red cell aplasia and chronic anaemia. Likewise, foetuses with the immature immune response are likely to be susceptible to the infection, which can lead to intrauterine foetal death and generalised foetal oedema $(2,6,7)$.

Infections occur endemically worldwide; their only source are infected individuals, often immunodeficient, which favors long-term excretion of the virus. The infection spreads mainly via droplets and direct contact with airway secretions. Another way of transmission is transfusion of blood and preparations containing the coagulation factors VII and IX. Still another possibility is the infection of a foetus through the placenta in viraemic mothers. Parvovirus B19 infections can occur as periodic epidemics affecting pre- and early-school children, especially in late winter or spring $(5,6,7)$.

The aim of the study is to discuss the pathomechanism of B19 action, particularly its effects on the hepatocytes; moreover, it is emphasisedthat B19 infection should be considered in differential diagnosis of patients presenting with hepatitis of unclear aetiology. 


\section{Case report}

A 12-year-old boy was referred from a district hospital to the Department of Paediatrics and Gastroenterology due to elevated inflammatory parameters, hypertransaminasemiaaccompanied by the features of cholestasis, direct hyperbilirubinemia. The history taken: one loose stool, abdominal pain preceding defecation three days before hospitalisation. The next day - fever, epigastric pain. The subsequent day- one episode of vomiting, fever, nausea, lack of appetite. On admission - yellow discolouration of the skin and dark urine; the patient's condition was relatively good, no spontaneous symptoms, normal temperature. The physical examination showed yellow pigmentation of the skin, sclera and oral mucosa. The liver with soft borders palpable $2 \mathrm{~cm}$ below the costal arch, the spleen impalpable. The additional tests demonstrated elevated inflammatory parameters (CRP $4.98 \mathrm{mg} / \mathrm{dl}$, PCT $2.14 \mathrm{ng} / \mathrm{ml}, \mathrm{SR} 83 \mathrm{~mm} / \mathrm{h}$ ), hypertransaminasemia ( ALT $121 \mathrm{U} / \mathrm{l}$, AST 52 U/l) with the features of cholestasis (GGTP $294 \mathrm{U} / \mathrm{l}$, total bilirubin $5.85 \mathrm{mg} / \mathrm{dl}$, conjugated bilirubin $5.21 \mathrm{mg} / \mathrm{dl}$ ). In the haemostasis system - normal INR, elevated D-dimers and fibrinogen. The abdominal US scan did not confirm the features of cholangitis yet demonstrated hepatosplenomegaly. The tests were performed to detect autoimmune and metabolic diseases causing hepatitis. Their findings allowed to exclude HBV, HCV, HAV, CMV, EBV infections,alpha-1 antitrypsin deficiency, Wilson disease, and coeliac disease. Moreover, poorly positive titre of ANAs, normal protein electrophoresis, and normal concentration of total IgG were observed. The serological test disclosed positive titre of antiparvovirus B19 antibodies, both in the IgM and IgG class. The patient was treated with Biotaxim, Aciclovir and Proursan. Thanks to the treatment applied, the complaints subsided and the laboratory results normalised. Based on the entire clinical picture and test results, the parvovirus B19 infection was found to be the most likely cause of hepatitis.

\section{Discussion}

Liver damage caused by parvovirus B19 infection may manifest with elevated levels of transaminases and result in acute hepatitis leading to fulminant liver failure or induce chronic hepatitis. Parvovirus B19-associated hepatitis may occur in $4.1 \%$ of infected patients. In most cases, acute B19 hepatitis shows complete and spontaneous remission, especially in adults. Fulminant liver failure caused by acute B19 infection is still a rare clinical entity. The data are underestimated due to a low number of tests and lack of awareness. Liver biopsy of the affected patients demonstrates cellular and canalicular cholestasis, apoptosis and necrosis, the extend of which depends on the immune status of the host and the severity of liver involvement.

The mechanism of parvovirus B19 infection-induced liver damage has not been fully elucidated. One of the options is direct hepatocellular damage resulting from viral infection. Alternatively, the damage may result from the indirect immune response to the virus $(8,9,10)$.

Direct cytopathic effect

Parvovirus B19 is a DNA single-stranded virus, whose genome contains 2 open reading frames (ORFs) encoding non-structural protein NS1 (at the5' terminus) and capsid proteins VP1 and VP2 (at the 3' terminus). VP2 is the main structural protein constituting $96 \%$ of all capsid protein. 
The minor capsid protein VP1 is identical to VP2apart from the addition of 227 amino acids (called theVP1 unique region) at its amino terminus and constitutes the remaining $4 \%$ of the capsid protein. VP1 is likely to play a significant role in tissue tropism. The non-structural protein (NS1) is located in the N-terminal genome region and its molecular mass is70 - 77 $\mathrm{kDa}$. The function of NS1 has not been fully explained. NS1 is considered essential for viral DNA replication and is involved in the regulation of viral promotors. The hepatocytes contain the globoside (antigen P) and glycosphingolipids in the cell membrane, which are thought to act as receptors for B19. The B19 virus enters the hepatocytes via the globoside, resulting in limited infection with the production of NS1 yet without the production of progeny viruses. The NS1 expression plays a pivotal role in arresting the cell in the G1 phase caused by the B19 virus. Moreover, the NS1 expression significantly increases the expression of p21/WAF1, the cyclin-dependent kinase inhibitor that induces this process. Ultimately, the G1-arrested hepatocytes undergo apoptosis through the activation of caspase-3 and caspase-9 $(3,9,11)$.

\section{Indirect mechanism of action}

The hepatotoxic effect induced by parvovirus B91 infection is thought to be caused by the increased number of circulating cytotoxic CD8+T cells and secretion IFN- $\gamma$ and TNF- $\alpha$ by these cells. LymphocytesCD8+ Tcause abnormal differentiation of monocytes and macrophages, decrease the level of circulating IL- 1 and increase the secretion of TNF- $\alpha$, IFNyand IL-2, which leads to hepatocellular damage followed by acute hepatitis $(8,12,13)$.

Diagnosis of parvovirus B19 infection

During the first stage of infection when anti-B19 antibodies are not yet detected (the serological window), parvovirus B19 DNAemia in peripheral blood reaches the highest level. About two weeks after the virus invasion into the body the production of $\operatorname{IgM}$ antibodies is initiated. Their occurrence starts the second stage of infection and correlates with a reduction in DNAemia. The seroconversion is observed about one week after the appearance of IgM antibodies; simultaneously the anti-B19 $\mathrm{IgG}$ antibodies are started to be produced while the IgM antibodies disappear. It is assumed that specific $\mathrm{IgG}$ antibodies stay in the body throughout the life $(1,6,8)$.

The serological methods are based on testing of anti-B19 IgM and IgG antibodies by means ofthe enzyme linked immunosorbent assay (ELISA) or western blot. ELISA detects anti VP1 and VP2 IgM and IgG antibodies. The western blot can be used to supplement ELISA, it enables the differentiation of the immune response of the affected individual against VP1, VP2 and NS1 of the B19 parvovirus. Thanks to that, the stage of infection can be determined (acute, chronic injection, reinfection) $(1,6)$.

The molecular methods are based on nucleic acid detection; they are modern and sensitive tools for diagnosing parvovirus B19 infection. The modern method most widely used is realtime PCR, which detects single copies of the virus in various materials, e.g. total blood, plasma, serum, amniotic fluid, tissues $(6,8,13)$. 


\section{In conclusion}

Since B19-induced infections are not recorded and diagnostic tests are not widely performed, the exact incidence rate is not known. Nevertheless, the population-based serological studies have revealed that parvovirus B19 infections are widespread in each age group. Such infections are likely to induce hepatocellular damage; therefore, the viral aetiology should always be considered while diagnosing hepatitis.

\section{References:}

1.Heegaard ED, Brown KE. Human parvovirus B19. ClinMicrobiol Rev. 2002;15(3):485-505. doi:10.1128/cmr.15.3.485-505.2002

2. Cohen B. Parvovirus B19: an expanding spectrum of disease. BMJ. 1995;311(7019):15491552. doi:10.1136/bmj.311.7019.1549

3.Gurda BL, Parent KN, Bladek H, Sinkovits RS, DiMattia MA, Rence C, Castro A, McKenna R, Olson N, Brown K, Baker TS, Agbandje-McKenna M. Human bocavirus capsid structure: insights into the structural repertoire of the parvoviridae. J Virol. 2010;84(12):58809. doi: 10.1128/JVI.02719-09.

4.Mihály I, Trethon A, Arányi Z, Lukács A, Kolozsi T, Prinz G. Observations on human parvovirus B19 infection diagnosed in 2011.Orvosihetilap. 2012;153(49):1948-1957. https://doi.org/10.1556/OH.2012.29447

5.Siennicka J, Stefanoff P, Trzcińska A, Rosińska M, Litwińska B. Przegląd serologiczny w kierunku zakażenia parwowirusem B19 w Polsce. Przegl Epidemiol. 2006;60:571-580.

6.Dzieciątkowski T, Tomaszewska A, Majewska A, Łuczak M. Zakażenia ludzkim parwowirusem B19. Post Mikrobiol. 2007;46(3):203-210

7. Kuchar E. Choroby wywołane przez parwowirus B19 u dorosłych. Avalaible from: https://www.mp.pl/pacjent/choroby-zakazne/choroby/zakazenia-wirusowe/157636,chorobywywolane-przez-parwowirus-b19-u-doroslych

8.Bihari C, Rastogi A, Saxena P, Rangegowda D, Chowdhury A, Gupta N, Sarin SK. Parvovirus b19 associated hepatitis. Hepat Res Treat. 2013;2013:472027. doi: $10.1155 / 2013 / 472027$.

9.Poole BD, Karetnyi YV, Naides SJ. Parvovirus B19-induced apoptosis of hepatocytes. J Virol. 2004;78(14):7775-83. doi: 10.1128/JVI.78.14.7775-7783.2004.

10.Díaz F, Collazos J. Hepatic dysfunction due to parvovirus B19 infection. J Infect Chemother. 2000;6(1):63-64.

11. Morita E, Nakashima A, Asao H, Sato H, Sugamura K. Human parvovirus B19 nonstructural protein (NS1) induces cell cycle arrest at G(1) phase. J Virol. 2003;77(5):291521. doi: 10.1128/jvi.77.5.2915-2921.2003.

12.Young NS, Brown KE. Parvovirus B19. N Engl J Med 2004; 350:586-597 doi: 10.1056/NEJMra030840

13.Hatakka A, Klein J, He R, Piper J, Tam E, Walkty A. Acute hepatitis as a manifestation of parvovirus B19 infection. J Clin Microbiol. 2011;49(9):3422-4. doi: 10.1128/JCM.00575-11. 